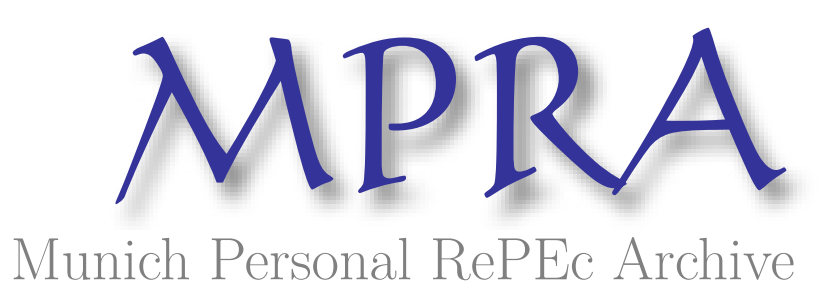

\title{
Economical Efficiency of Poultry Projects for Chicken Meat Production
}

Anwar, A. and A.Shamma, T. and Soliman, I.

Animal Production Department, Faculty of Agriculture, Ain-Shams University, Cairo, Egypt.

May 1977

Online at https://mpra.ub.uni-muenchen.de/66529/

MPRA Paper No. 66529, posted 14 Sep 2015 04:25 UTC 


\section{Economical Efficiency of Poultry Projects for Chicken Meat Production}

\section{A. Anwar, T. A. Shamma and I. Soliman}

Animal Production Department, Faculty of Agriculture, Ain-Shams University, Cairo, Egypt.

\section{INTRODUCTION}

TN chicken projects for meat production, the two most important factors involved in the achievement of maximum recovery of capital are feeding cost and finishing time.

Feeding cost stands for more than two thirds of all the expenses (Ewing, 1963) while finishing time is entirely dependent upon the limiting growth unit (Scott et al. 1969). Accordingly, the economical efficiency of the product could be calculated from the input-output analysis based upon the differences in both growth rates and feeding cost. The other items included are of less importance.

The present survey therefore, was collected from data obtained for foreign, local and cross strains of chicks when the last two strains are fed relatively cheaper rations or finished at different final weights in order to achieve the maximum economical efficiency.

\section{Experimental}

The strains of chicks included in this study were the foreign strain Nichols, the local strain Fayoumi and the cross strain Dokki 4 (Fayoumi $\times$ Plymouth Rock). An adequate number of day-old chicks from each of the strains Dokki 4 and Fayoumi vaccinated against Newcastle were distributed by the Ministry of Agriculture among poultry farms. An equal number of Nichols, produced and reared by the poultry Organisation, Cairo, were taken as standard for comparison.

Three feeding rations containing the optimal requirements for Nichols, Dokki 4 and Fayoumi, respectively were formulated as given in table 1 (Shamma, 1973). Ration 1 contained 40 gross protein value units (G.P.V.Us) and $2200 \mathrm{Kcaloric}$ of productive energy (P.E.) per $\mathrm{Kg}$. ration, while rations 2 and 3 contained $35: 2000$ and $30: 1800$ per $\mathrm{Kg}$. for the two values, respectively. The protein units were calculated by the method of Anwar (1967), while the productive energy contents were obtained from the tables of Anwar (1973) for local ingredients. The differences in the calorie protein ratio caused the price of ration to differ accordingly, due to the incorporation of more protein supplements (table 1). The price per ton was 65,40 and 35 L.E.* for the three

- L.E. $=1$ pound Egyptian currency $=100$ piastres. 
TABLE 1: The experimental rations used in the feeding trials containing different levels of protein quality and calorific values.

\begin{tabular}{|c|c|c|c|c|c|c|c|c|c|}
\hline & & & & & & & 1 & $\underset{2}{\text { Rations }}$ & 3 \\
\hline \multicolumn{10}{|c|}{ Ingredients (g./Kg.) } \\
\hline Corn & $\ldots$ & $\ldots$ & $\ldots$ & & $\ldots$ & $\ldots$ & 600 & 550 & 500 \\
\hline Wheat Bran & $\ldots$ & $\ldots$ & $\ldots$ & $\ldots$ & $\ldots$ & $\ldots$ & - & 50 & 70 \\
\hline Rice Bran... & $\ldots$ & $\ldots$ & $\ldots$ & ... & $\ldots$ & $\ldots$ & - & 50 & 100 \\
\hline \multicolumn{5}{|c|}{ Soyabean Meal +(DL \pm$)$ Methionine } & $\ldots$ & $\ldots$ & 200 & $\overline{20}$ & - \\
\hline Cottonseed M & & $\ldots$ & $\ldots$ & $\ldots$ & $\ldots$ & $\ldots$ & - & 175 & 200 \\
\hline Fish Meal & $\ldots$ & $\ldots$ & $\ldots$ & $\cdots$ & $\ldots$ & $\ldots$ & 70 & 50 & 25 \\
\hline Meat Meal & $\ldots$ & $\ldots$ & $\ldots$ & ... & ... & $\ldots$ & 30 & 75 & 55 \\
\hline Bone Meal & $\ldots$ & ... & $\ldots$ & $\ldots$ & $\ldots$ & $\ldots$ & 20 & 10 & 10 \\
\hline Clover Meal & $\ldots$ & $\ldots$ & $\ldots$ & $\ldots$ & $\ldots$ & $\ldots$ & - & 20 & - \\
\hline Vit. Mix.... & $\ldots$ & $\ldots$ & $\ldots$ & $\ldots$ & $\ldots$ & $\ldots$ & 10 & 5 & 5 \\
\hline Min. Mix. & $\ldots$ & $\ldots$ & $\ldots$ & $\ldots$ & $\ldots$ & $\ldots$ & 10 & 5 & 5 \\
\hline Tallow $\quad .$. & $\ldots$ & $\ldots$ & $\ldots$ & $\ldots$ & $\ldots$ & $\ldots$ & 40 & - & - \\
\hline Salt $\quad \ldots$ & & ... & ... & $\ldots$ & $\ldots$ & $\ldots$ & 10 & 10 & 10 \\
\hline \multicolumn{2}{|c|}{ Calcium Carbonate } & $\cdots$ & $\cdots$ & $\cdots$ & $\cdots$ & $\cdots$ & 10 & 一 & - \\
\hline \multirow{5}{*}{\multicolumn{3}{|c|}{ 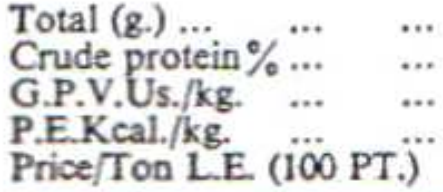 }} & $\cdots$ & $\cdots$ & $\cdots$ & $\cdots$ & 1000 & 1000 & 1000 \\
\hline & & & $\cdots$ & $\cdots$ & $\cdots$ & $\cdots$ & 23 & 22 & 20 \\
\hline & & & $\cdots$ & $\ldots$ & $\cdots$ & $\ldots$ & 40 & 35 & 30 \\
\hline & & & $\ldots$ & $\cdots$ & $\cdots$ & $\cdots$ & 2200 & 2000 & 1800 \\
\hline & & & $\ldots$ & $\ldots$ & $\ldots$ & $\ldots$ & 65 & 40 & 35 \\
\hline
\end{tabular}

rations, respectively. The rations were fed to chicks, each to the corresponding strain, from day-old up to $1 \mathrm{~kg}$ of live weight.

The Input-Output analysis was done using the method of Heady and Jensen (1954) taking the economical efficiency of Nichols as standard with which those for Dokki 4 and Fayoumi were compared. The values of economical efficiency were calculated as the net revenue per unit of total cost per year of production.

A farm scale of L.E. 5,000 capital was used in the analysis with the capacities of $10,000,12,500$ and 15,000 birds of Nichols, Dokki 4 and Fayoumi respectively. The data obtained were tabulated, as given in table 2, at six weeks when Nichols reached the marketing weight of $1 \mathrm{Kg}$. and each 2 weeks then after for the other two strains. Dokki 4 reached the weight of $1 \mathrm{Kg}$ at 10 weeks and Fayoumi at 12 weeks of age

\section{Results and Discussion}

Since the meat strain Nichols which was taken as standard for comparison succeeded to reach the marketing weight of $1.083 \mathrm{Kg}$. at 6 weeks of age seven turns of production per year were achieved giving a total yield of 75.74 tons of live weight (table 2). The input-output analysis for this strain (table 3 ) showed the yearly total cost of L.E. 19,064 and the total revenue of L.E. 30,296 producing the net revenue of L.E. 11,232 . Therefore, the economical efficiency for this strain calculated as the part of the total cost that is recovered was 0.59 (table 4). 


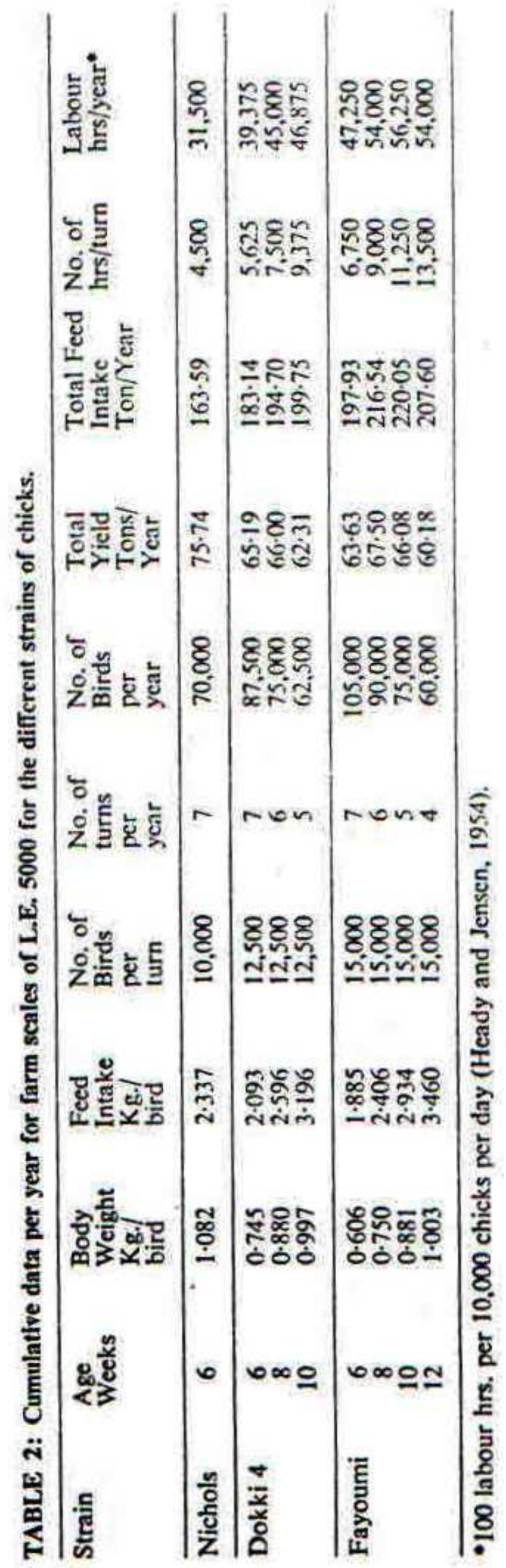




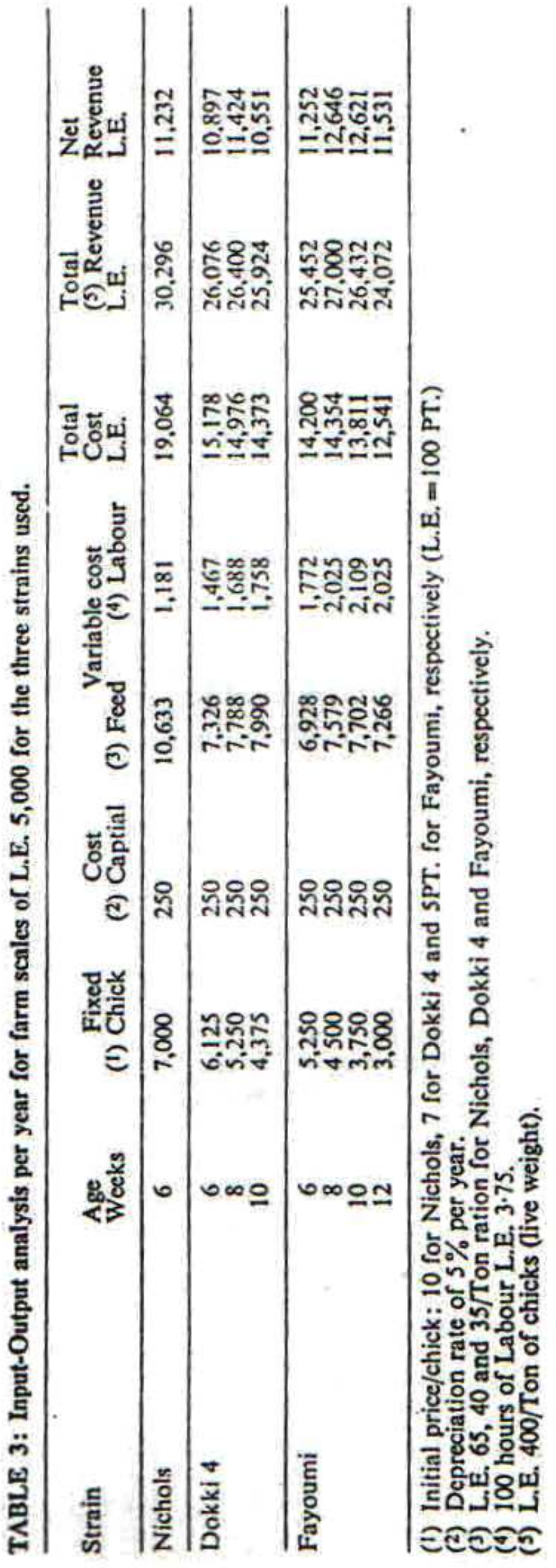




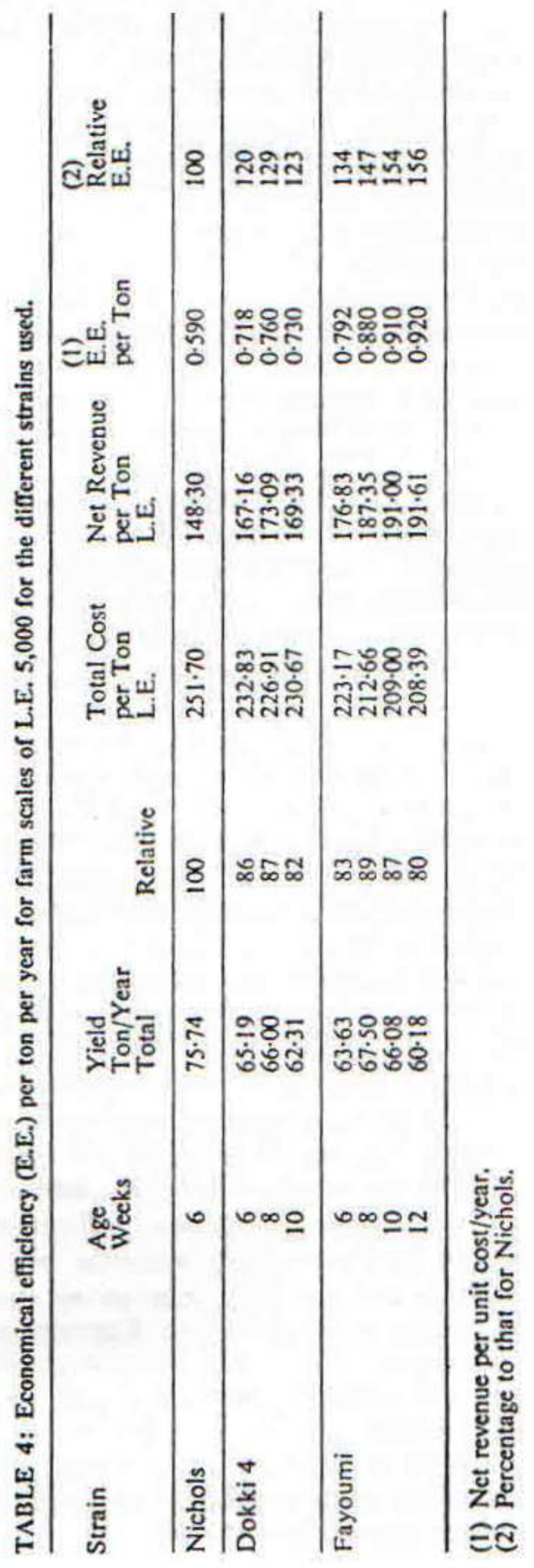


When the same input-output analysis was applied to Dokki 4 chicks the marketing weight of $0.997 \mathrm{Kg}$. was achieved at 10 weeks of age (table 2). Accordingly only 5 turns per year were practised giving the total yield of 62.500 tons of live weight. The yearly total cost was L.E. 4,373 and the total revenue was L.E. 24,924 giving the net revenue of L.E. 10,551 (table 3). The economical efficiency (E.E.) of this cross strain when marketed at $1 \mathrm{Kg}$. of live weight was 0.73 (table 4). These results show that despite that the total yearly production of Dokki 4 was only $82 \%$ of that of Nichols yet its economical efficiency was higher $(123 \%)$ as given in table 4 . The reason for making the better performance of Nichols was the relatively higher total cost which was mainly due to the expensive ration used. However when this comparative study was applied to Dokki 4 at the same marketing time as that of Nichols (6 weeks) the total yearly production was $65 \cdot 19$ tons (table 2) giving the E.E. of 0.718 (table 4). The relative values for these two figures to those for Nichols were 86 and $120 \%$ (table 4). At 8 weeks of age ( 6 turns) the total yield increased to 66.00 tons of chicken live weight giving the E.E. of 0.76 with the relative values of 87 and $129 \%$ to those for Nichols. It seems that the cross strain Dokki 4 gives its best yearly production with the maximum E.E. when marketed at 8 weeks of age.

In the case of Fayoumi chicks, they reached the live weight of $1.003 \mathrm{~kg}$. at the age of 12 weeks with only 4 turns of production pei year (table 2). The total yield was $60 \cdot 18$ tons of chicken live weight with the total cost of L.E. 12,541 and the total revenue of L.E. 24,072 having the difference of L.E. 11,531 as net revenue. This value was very near to that for Nichols, but the economical efficiency was 0.92 instead of 0.59 for Nichols. These findings prove that despite the fact that Fayoumi chicks took twice as much time as that of Nichols to achieve the same marketing weight, yet on total cost basis the performance of this strain was very profitable since its feeding requirements are practically fulfilled by the lowest feeding cost (table 1 ). The relatively yearly production from Fayoumi was $80 \%$ while the E.E. was $156 \%$ for the two relevant values for Nichols, respectively (table 4).

On the other hand, the yearly production of Fayoumi at 6,8 and 10 weeks of age was $63.63,67.50$ and 66.08 as having the relative values of 83.89 and $87 \%$ of that achieved by Nichols, respectively (table 4 ).

The economical efficiency at the three marketing times for Fayoumi were $0.79,0.88$ and 0.91 while the relative values to that for Nichols were 134,147 and $154 \%$, respectively (table 4 ). For the achievement of maximum production from Fayoumi chicks the 8 weeks marketing time seems to be the best while for maximum economical efficiency the 12 weeks marketing time comes first. However if the two considerations were joined it seems that the 10 weeks marketing time should be practiced. It is not advisable to exceed the age to 12 weeks in order to make very slight profit $(0.91-0.92)$ on the account of almost 6 tons of chicken live weight (table 4). 


\section{Summary}

A farm scale of L.E. 5,000 and the capacity of $10,000,12,500$ and 15,000 chicks of Nichols, Dokki 4 and Fayoumi chicks, respectively was subjected to an input-output analysis for maximum economical efficiency. The optimal feeding requirements for the three strains were achieved in the relevant experimental rations which cost L.E. 65,40 and 35 , respectively. The chicks reached the live weight of $1 \mathrm{~kg}$. at 6,10 and 12 weeks of age for the three strains respectively. However on total cost basis, the results obtained for the economical efficiency were reversed. It seems that one item such as the growth rate is not enough to judge the efficiency of poultry projects but all the items concerned with the production of a unit which cost less to produce.

Resume

EFFICACITE ÉCONOMIQUE DES PROJETS AVICOLES POUR LA PRODUCTION DE VIANDE DE POULET

Des fermes à l'échelle de 5000 L.E. et d'une capacité de 10000,12500 et 15000 poulets Nichols, Dokki 4 ou Fayoumi ont été soumises à une analyse "in put-out put" en vue d'une efficacité économique maximum. Les besoins alimentaires optimaux pour les trois lignées étaient couverts par des rations expérimentales coûtant 65,40 et 35 L.E. respectivement. Les poulets atteignaient le poids vif de $1 \mathrm{~kg}$ à 6,10 et 12 semaines d'âge respectivement pour les trois lignées. Cependant, sur la base d'un coút total, les résultats obtenus pour l'efficacité éonomique étaient inversés. Il semble qu'un seul critère tel que la vitesse de croissance soit insuffisant pour juger de l'efficience d'un projet avicole, mais que Texamen de l'ensemble des critères concernant la production d'une unité soit nécessaire.

\section{Zusammenfassung \\ WIRTSCHAFTLICHE EFFIZIENZ VON GEFLÜGELPROJEKTEN ZUR FLEISCHERZEUGUNG.}

Farmen mit einer Kapazităt von 10000,12500 und 15000 Hühnern der Rassen Nichols, Dokki 4 und Fayoumi wurden einer input-output Analyse hinsichtlich der maximalen wirtschaftlichen Effizienz unterzogen. Die optimalen Füterungsbedingungen der drei Rassen wurden mit Versuchsrationters erzielt, die 65, 40 bzw, 35 LE. kosteten. Ein Körpergewicht von $1 \mathrm{~kg}$ erreichten die drei Rassen nach $6,10 \mathrm{bzw}$. 12 Lebenswochen. Unter Zugrundelegung der Gesamtkosten ergab sich für die wirtschaftliche Effizienz der Rassen die umgeketirte Rangfolge. Es hat den Anschein als ob eine Einflußgröße wie die Wachstumsrate nicht ausreicht, um die Effizienz von Gefiügelprojekten zu beurteilen, sondern die Berücksichtigung aller EinfluBgrößen erforder, die auf die Erzeugung einer Einheit kostensenkend oder erböhend Einfluß nehmen.

\section{References}

ANWAR, A (1967). Gross protein value units in the standardisation of rations for Fayoumi chicks. ANWAR, A. (1973). Poultry Nutrition: 2nd Ed. Modern Press, Cairo, Egypt.

EWING, W. R. (1963). Poultry Nutrition. Sth Ed. Pasedena, U.S.A.

HEADY, E O. and H. R. JENSEN, (1954). Farm Managtment Economics. Prentice-Han, Ioc, SHAMMA, T. A. (1973). Caloric: Protein ratio in the feeding of broilers. M.Se. Thesis, Ain-Sherms

University. Cairo, Egypt.
SCOT, M. L. M. C NESHEIM and R. J. YOUNG, (1969). Nurrltion of the chicken. Ist Ed. Ithaca,
U.S.A. 